\title{
Probiotics for Diarrhea in Children
}

\section{ABSTRACT}

Diarrhea remains the second leading cause of death in children below 5 years of age; in addition it is also the reason for a considerable morbidity in children of all ages throughout the globe. Apart from oral rehydration solution, continued feeding, oral zinc and antibiotics for diarrhea of bacterial etiology, there have been no other proven measures for diarrheal illnesses in children. Probiotics are non-pathogenic live microorganisms. When ingested, probiotics can survive passage through the stomach and small bowel. Probiotics are supposed to have preventive as well as curative effects on several types of diarrhea of different etiologies.

Keywords: Gastroenteritis, Saccharomyces, Bifidobacterium, Functional food.

\section{Introduction}

Diarrheal disease is responsible for a huge burden on human society. Even with improvements in the case management, diarrhea is responsible for 1.5 million deaths annually, or $1 \%$ of deaths in children under 5 years. Although the majority of these deaths occur in the developing world, it is a common reason for medical consultation and hospital admission in Western societies and exacts an enormous social toll in terms of loss of productivity among affected individuals and their caregivers [1].

Probiotics, commonly known as "good bacteria" can offer health benefits in a number of ways when consumed. The use of probiotic microorganisms for the prevention or therapy of gastrointestinal disorders is an obvious measure and perhaps the most usual application of probiotics because most health effects attributed to them are related directly or indirectly to the gastrointestinal tract [2]. In this review, we summarize the available evidence on the use of probiotics for diarrheal diseases in children.

\section{History}

The health benefits of bacteria consumed in food have been known since ages; records dating back to as early as the Persian version of the Old Testament. Noble laureate Elie Metchnikoff in 1908 suggested that products of proteolytic bacterial action on protein resulted in "intestinal autointoxication". He presented a hypothesis that consumption of yogurt containing Lactobacillus lead to reduced number of toxin-producing bacteria in the intestine and thus contributed to the long life of Bulgarian peasants [3]. The concept of probiotic is derived from the Greek word meaning "for life" and the term came into practice in 1965 [4]. Since then the interest in probiotics has grown many folds and currently, the market for probiotics has reached to over 60 billion USD [5].

\section{Definition and properties of probiotics}

The FAO/ WHO defines probiotic as a "live microorganism which, when administered in adequate amounts, confer a health benefit to the host" [6]. Following this, the -

\section{Article Details}

Date Received: 30/04/2017 Date Revised: 05/05/2017 Date Accepted: 07/05/2017 Date Published: 07/05/2017 DOI: 10.5281/zenodo. 574854 Editor(s): Varshil Mehta

\section{Author Affiliation}

1. Department of Pediatrics, Sitaram Bhartia Institute of Science and Research, New Delhi, India.

2. Department of Pediatrics, Kalawati saran Children's Hospital, New Delhi, India.

\section{Corresponding Author}

Anirban Mandal

Address: Department of Pediatrics, Sitaram Bhartia Institute of Science and Research, New Delhi, India.

Email I’d: anirban.nrs@gmail.com

Copyright: (c) 2017. The Author(s). This is an open access article under the CC BY license. (http://creativecommons.org/lice nses/by/4.0)

\section{Financial or Comepeting} Interest: None

\section{Cite as:}

Mandal, A., \& Sahi, P. (2017). Probiotics for Diarrhea in Children. Journal Of Medical Research And Innovation, 1(2), AV5-AV12. doi:10.5281/zenodo.574854 
International Life Science Institute (ILSI) [7] and the European Food and Feed Cultures Association (EFFCA) [8] have given similar definitions for probiotic: "a live microbial food ingredient that, when consumed in adequate amounts, confers health benefits on the consumers". The properties of an ideal probiotic should be [9]:

- of human origin

- nonpathogenic

- contains sufficient number of viable cells

- unaffected to destruction by technical processing

- unaffected to destruction by gastric acid and bile

- adhere to intestinal epithelium

- able to inhabit the gastrointestinal tract, even if for a short time

- $\quad$ producing antimicrobial substances

- modulating immune responses

- influencing human metabolic activities (i.e. cholesterol assimilation, vitamin production) and

- undergone in vivo and in-vitro trials to prove any attributed probiotic effect and documented a clinical benefit

\section{Common probiotic strains}

Various organisms (bacteria and fungus) have been identified as meeting the diagnostic criteria for probiotics. The common ones are presented in (table 1).

\begin{tabular}{|l|l|l|}
\hline Bifidobacterium spp & \multicolumn{1}{l}{ Lactobacillus } & \multicolumn{1}{l|}{ Saccharomyces } \\
\hline B. bifidum & L. acidophilus & S. boulardii \\
\hline B. breve & L. casei & \\
\hline B. lactis & (rhamnosus) & \\
\hline B. longum & L. fermentum & \\
\hline B. infantis & L. gasseri & \\
\hline B. adolescents & L. lactis & \\
\hline & \\
& \\
\hline B. paracasei & & \\
\hline
\end{tabular}

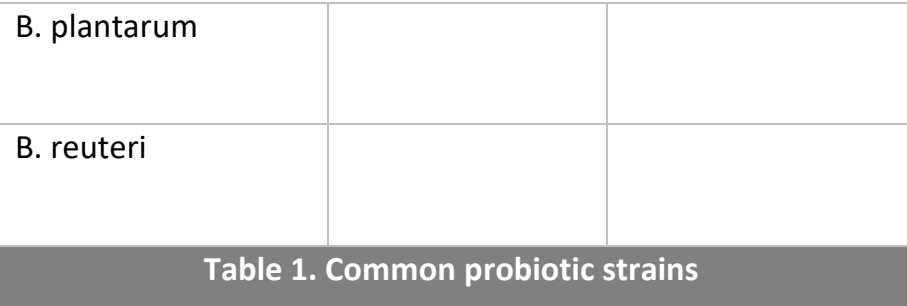

\section{The indigenous intestinal flora}

There are an estimated 1014 cells in human body, and out of this only $10 \%$ are not bacteria. The gastrointestinal tract of mammals is a complex, dynamic and diverse ecosystem comprising of interactions between aerobic and anaerobic, nonpathogenic bacteria. There are 400 separate species in this complex yet stable colony. The majority of the gut organisms, which represent $40 \%$ of the fecal weight, are accounted for by luminal flora; nevertheless, the organisms present in the fecal matter do not necessarily signify the important host-microbial symbiosis of the mucosal bound flora [10]. Within first few days after birth, the newborn's gut is colonized with bacteria. A diverse range of bacteria inoculates the gut initially; this includes Bifidobacteria, Enterobacteria, Bacteroids, Clostridia, and Gram-positive cocci. Later on, there are swift changes in the flora depending on the mode of delivery, gestational age, and diet (breastfeeding/ formula feeding). Vaginally delivered breastfed infants have similar colonization to vaginally born formula-fed infants at 48 hours of life, indicating a similar "inoculums". However, by 7 days, only $22 \%$ of breastfed infants are colonized with B. fragilis, as compared to $61 \%$ of those fed on formula [11]. Interestingly, there is a minimal role of diet in the composition of fecal flora in the older child and adult [12].

Fungi are present in the stools of up to $65 \%$ of individuals, Candida being the predominant genus. It appears that pathogenic colonization by yeast, under normal circumstances, is inhibited by the normal bacterial flora. However, alteration or destruction of the fecal flora by antibiotics would lead to yeast multiplying in great numbers [13].

\section{Mechanism of action of probiotics in diarrhea}

Although animal and molecular studies have generated a great deal of data, most theories remain speculative and confirmation of findings in vivo and in human clinical trials have been lacking. Almost certainly multiple mechanisms operate together and it is clear that single strains may act using different mechanisms in different disease processes [14].

Luminal: Many probiotic organisms elaborate 'bacteriocins', restricting the growth or pathogenicity of non-homologous strains. Other probiotic activities including the production of lactic acid, short chain fatty acids and hydrogen peroxide lower intraluminal $\mathrm{pH}$ and contribute to a hostile environment for other potentially pathogenic species. Some probiotic products, 
such as proteases produced by Saccharomyces boulardii have been shown to degrade toxins produced by pathogens such as Clostridium deficile, Vibrio cholera or pathogenic Escherichia coli [15]. Additionally, probiotics metabolic activity may have useful nutritional or clinical activity. It has long been appreciated that the enzyme $ß$-galactosidase produced by lactobacilli may be useful in preventing diarrhea in individuals with acquired deficiency of this enzyme [16].

Mucosal: Some probiotic agents are able to bind directly to invasive species or to otherwise disrupt their ability to interact with or bind to endothelial receptors. Probiotics including several species of Lactobacillus have been shown to upregulate goblet cell production of mucins and protective 'trefoil factors'. They also stimulate crypt located Paneth cells in the production of 'defensins', cationic proteins which are able to insert themselves into microbial membranes to form destructive pores. In addition, probiotics may also influence proteins controlling tight junctions between enterocytes, reducing the potential for the absorption of harmful macromolecules and the ability of luminal pathogens to translocate into the submucosal space [17].

Submucosal: Critical to the development of innate immunity is the system for recognizing microbe-associated molecular patterns (MAMPs)-conserved regions comprising motifs or repeating units from a wide range of molecules including lipopolysaccharides, peptidoglycans, and nucleic acids found more frequently on the surface of microbial species than on host cells. These pattern recognition receptors (PRRs) including the toll-like receptors (TLR) on the surface of host cells (including dendritic cells in the gut) are key determinants of detection and host interaction directing subsequent effector response [18]. Adaptive immune responses have also been shown to be influenced by the presence of probiotic organisms, some of which are able to stimulate immunoglobulin (particularly secretory IgA) production and to modulate the development and activity of regulatory T-lymphocytes. Similarly, probiotics are known to influence the pattern of cytokine release as well.

It is likely that host-microbe signaling takes place continuously rather than awaiting recruitment at the time of disease. The potential for probiotics to influence this series of interactions through the activation of NF-Kß, thereby controlling DNA transcription, the inflammatory response and the balance of TH1/TH2 activation, hold exciting promise for the ability of these agents to influence chronic inflammatory processes [19]. Such effects are also likely to be important in modulating the immune response to acute infection within the gastrointestinal tract.

The molecular interactions between host and microbiota have been shown to have an influence on the enteric nervous and endocrine systems. Experimental work has identified the activity of certain probiotic species in inducing opioid and cannabinoid receptors in the gastrointestinal tract as well [20].

\section{Probiotics for diarrhea of viral origin}

Viral agents are responsible for acute diarrheal episodes in children throughout the world with Rotavirus being the most important agent. A Cochrane database of systematic review compiled pooled estimates of benefit for Lactobacillus in acute rotavirus diarrhea [Allen SJ 21] and found a reduction in the duration of diarrhea of 29 hours (95\% Cl 16-42 hours), a reduction in stool frequency on day 2 following the intervention of 1.25 stools per day ( $95 \% \mathrm{Cl} 0.4-2.1)$. Grandy et al [22] studied S. boulardii alone or in combination with three other probiotics including two strains of Lactobacillus in rotavirus diarrhea. Both products seemed to be associated with a reduction in the duration of diarrhea. However, a Turkish study found benefit in terms of reduced duration of diarrhea for one of only four intervention groups given S. boulardii [23].

Although a number of treatment studies have reported the detection of other (i.e. non-rotavirus) viral agents [24, 25], individual isolates have been few in number and no studies have reported primary or secondary outcomes for probiotics administered for acute diarrheal episodes attributable to specific viral etiologies other than rotavirus.

Similarly, studies of prevention of diarrheal disease have generally failed to provide evidence of protection against specific viral agents. A Peruvian study in the prevention of diarrhea in children aged 6-29 months reported a reduction in the detection of adenovirus from stool specimens in a cohort supplemented with Lactobacillus GG [26]. But, on the other hand, Sur et al. have found no difference in recovery rates for adenovirus, rotavirus, norovirus, or astrovirus for children from a deprived urban setting of India, receiving L. casei Shirota compared with a control cohort [27].

Children with HIV (Human immunodeficiency virus) infection comprise a special population which is susceptible to diarrheal illnesses due to a host of infections. The published studies on the efficacy of probiotics in the treatment of diarrhea in this population have come to disparate conclusions; some $[28,29]$ but not others [30,31], finding efficacy. In a large study of Malawian children with severe acute malnutrition [32], over $40 \%$ of whom were HIV positive, were randomized to receive a multicomponent probiotic containing lactobacilli or placebo. The study did not find an improvement in rates of diarrhea for probiotic recipients.

\section{Probiotics for bacterial diarrhea}

Two studies of Lactobacillus rhamnosus GG found no evidence of protection for the $15-20 \%$ of children with 'invasive' pathogens, principally Salmonella or Shigella [33]. In the only study specifically addressing bacterial disease, there was an earlier resolution of diarrhea for LGG (co-treated with trimethoprim-sulfamethoxazole) during an outbreak of Shigella dysentery in Estonia [34]. Hwe et al [35] described an 
improvement in stool consistency for 20 children with pathogenic E. coli cultured from the stool. However, a threespecies probiotic mixture including Escherichia faecium was not found to significantly reduce the duration of diarrhea due to Salmonella or Campylobacter in Taiwan [25]. Several studies using combination probiotic products (S. boulardii or E. coli Nissle 1917) in middle-income countries report overall efficacy for groups with significant (10-20\%) contributions from pathogenic species but sufficient data is not provided to assess efficacy by diarrheal pathogen [36, 37, 38, 39].

A large community prevention study from India [27] documented a reduction of diarrheal disease with Aeromonas and Cryptosporidium species in Lactobacillus casei Shirota recipients; though other bacteria (including pathogenic E. coli), viral and protozoal species were recovered at equivalent rates. Another study from urban India reported protection against dysentery (defined by a parental history of bloody diarrhea), although no impact was seen on the overall incidence of diarrhea [40].

\section{Probiotics for parasitic diarrhea}

A Cuban study in children with persistent diarrhea (35 out of 40 having giardial cysts in stool) improved with administration of S. boulardii [41]. In cases of amoebic dysentery, reduced duration of bloody diarrhea and a lower rate of cyst excretion on day 5 are reported in 25 Turkish children receiving Saccharomyces [41]. A randomized trial in 48 symptomatic children with Blastocystis hominis demonstrated higher rates of clinical cure and disappearance of cysts from the stool with probiotics [43].

\section{Probiotics for Clostridium defficile associated diarrhea (CDAD)}

Although a meta-analysis performed by McFarland for the treatment of CDAD found evidence in favor of treatment with S. boulardii [44], the Cochrane group and other reviewers [45, 46,47 ] have conclude that despite holding promise, currently data are not sufficient to make a recommendation for the use of Saccharomyces or other Probiotics for the treatment of primary or relapsing CDAD.

Five published studies of the use of Saccharomyces in the prevention of antibiotic-associated diarrhea (AAD) have provided secondary outcome measures for CDAD. Reviewers $[45,48,49]$ have concluded that inadequate evidence currently exists in order to make a recommendation concerning the role of $\mathrm{S}$. boulardii or other Probiotics in the primary prevention of CDAD.
Probiotics for antibiotic associated diarrhea (AAD)

There have been no published RCT investigating the effect of Probiotics for the treatment of non-Clostridium defficile $A A D$ in children; thus, their use cannot be recommended at this time.

A Cochrane meta-analysis of probiotic use of children to prevent or ameliorate (i.e. shorten duration and/ or severity) AAD [50] documents that probiotics produced a statistically significant reduction in the incidence of $A A D$ (RR $0.52 ; 95 \% \mathrm{Cl}$ 0.38-0.72) with the number needed to prevent one case of AAD being 7. Analysis of secondary outcomes revealed that probiotics decreased the mean duration of diarrhea by threequarters of a day. The difference in mean stool frequency was not statistically significant. Analysis by probiotic strain revealed a significant effect for $L G$ and Lactobacillus sporogenes but not for boulardii.

\section{Probiotics for traveler's diarrhea}

Several studies using lactobacilli have suggested benefit in protecting travelers from diarrhea, but in only one study using a mixture of strains (containing Lactobacillus acidophilus, Lactobacillus bulgaricus, Bifidobacterum bifidum and Streptococcus thermophilus) was the reduction in the overall incidence of diarrhea statistically significant [51]. Travelers to a variety of destinations including North Africa, South America, India and Turkey derived some measure of protection from S. boulardii [52]. Several attempts have been made to conduct meta-analysis from these data, estimating risk ratios marginally in favor of probiotics (RR estimates between 0.85 and 0.93 ) but with confidence intervals close to or encompassing the point of equivalence $[53,54,55]$.

\section{Probiotics for diarrhea in children attending day care centers}

One RCT documented that a daily administration of L. reuteri for 3 months in 336 otherwise healthy, Mexican children attending day care centers a significant reduction in the number of episodes of diarrhoea, episodes of diarrhoea per child, mean duration of diarrhoea episodes and days with diarrhea per child both during the intervention and for the next 3-month follow-up period compared to the placebo group [56]. Another RCT carried out in malnourished Indonesian children found that the consumption of regular calcium milk with $\mathrm{L}$. reuteri compared with regular calcium milk alone reduced the risk of diarrhoeal disease [57]. A double-blind RCT from Croatia in 210 children attending daycare centers found that that $B$. animalis subsp. lactis BB-12 given for months had no effect on the prevention of gastrointestinal [58]. 


\section{Probiotics for persistent diarrhea}

A Cochrane review of probiotics for persistent diarrhea [59] yielded a pooled estimate for reduction in the mean duration of diarrhea from 9 to 4 days, with significantly fewer stools on day 5 (a reduction from a mean of 5 to fewer than 2 stools per day).

\section{Probiotics for acute diarrhea of undetermined etiology}

A 2010 Cochrane database of systematic review provides a meta-analysis of 63 studies of probiotic agents involving more than 8000 participants, mostly children, conducted in a variety of geographical and social settings [21]. Overall conclusions suggest that probiotics shorten the duration of diarrhea by 24 hours $\{95 \%$ confidence interval $(\mathrm{Cl}) 16-33$ hours $\}$ and for a mean difference in stool frequency on day 2 of 0.8 (95\% $\mathrm{Cl} 0.4-1.1)$, with a relative risk of continuing diarrhea on day 4 of $0.4(95 \%$ $\mathrm{Cl}$ 0.3-0.5). No adverse effects were attributed in these studies to the administration of the probiotic.

There is still clearly much to learn about how best to use probiotics in acute diarrheal disease. Only a few studies have directly compared probiotic products [60-63] or ranged doses $[64,65]$. The Cochrane review [21] found similar pooled estimates of efficacy for studies conducted in countries categorized by high or low mortality, nevertheless, a preponderance of negative studies $[66,67,68,69,70,71]$ have been reported from resource-limited settings where infectious agents and the intestinal microbiota might be expected to be different from those of Western societies. Other little-explored influences on treatment include the role of prebiotic nutritional supplements, breastfeeding [26] or other dietary practices, the effects of accompanying or recent antibiotic treatment, the availability of clean water and adequate sanitation and other currently ill-defined influences on the resident microbiota.

Uncertainties aside, majority of reviewers and expert committees [65, 66, 67, 68, 69, 70, 71, 72, 73, 74, 75, 76], including American Academy of Pediatrics [77] and European Society of Pediatric Gastroenterology Hepatology and Nutrition (ESPGHAN) [78] have concluded that preparations containing probiotics (of the specific strains studied in these trials) both shorten the duration and reduce the severity of acute diarrhea in children.

\section{Safety of probiotics}

Probiotics are considered 'generally recognized as safe' (GRAS) and well tolerated in humans but case reports have described bacteremia and fungemia secondary to probiotics. For example, there is a report of a 1-year-old immunocompetent child developing fungemia after receiving $\mathrm{S}$. boulardii for gastroenteritis [79]. The Mayo Clinic reported eight immunocompromised patients post-liver transplant having positive blood culture for Lactobacillus [80]. Furthermore, two infants with short bowel syndrome were found to be bacteremic withprobiotic strains of Lactobacillus GG [81]. Longterm use of probiotics under antibiotic selection pressure could cause antibiotic resistance, and the resistance gene could be transferred to other bacteria [82]. The committee on Nutrition of the European Society of Pediatric Gastroenterology, Hepatology and Nutrition concluded that more studies are required to establish the safety and efficacy of probiotics in children. Till date safety of probiotics is established in healthy infants and children. Caution should be exercised when using these in immunocompromised patients or those with indwelling central venous catheters. It is out of the purview of The American Food and Drug Administration to establish a formal regulatory category for functional foods that includes probiotics. Variations in products do exist and some studies have even found that certain preparations contain no viable bacteria.

\section{Conclusion}

A low-cost probiotic intervention capable of reducing the risks of diarrhea in the early years of life, even with modest efficacy, would have an enormous impact on the developing world. Assuming that efficacy is confirmed for prevention and treatment of childhood diarrhea in these settings, a great deal of work will be needed for its broad implementation.

\section{References}

1. Walker, C., Rudan, I., Liu, L., Nair, H., Theodoratou, E., Bhutta, Z., et, a. (2013). Global burden of childhood pneumonia and diarrhoea. Lancet 381(9875), 1405-16. https://doi.org/10.1016/S0140-6736

2. De-Vrese, M., Marteau, P. (2007). Probiotics and prebiotics: effects on diarrhea. J Nutr 137(S3), 803S-11S.

3. Metchnikoff , I. (2004). The prolongation of life: optimistic studies. New York: Springer Publishing Company.

4. Lilly, D., Stillwell, R. (1965). Probiotics: growth-promoting factors produced by microorganisms. Science 147(3659), 747-8.

5. Probiotic Ingredients Market by Function (Regular, Preventative, Therapy), Application (Food \& Beverage, Dietary Supplements, \& Animal Feed), End Use (Human \& Animal Probiotics), Ingredient (Bacteria \& Yeast), and by Region - Global Trends \& Forecast to 2020.Available from: http://www.marketsandmarkets.com/PressReleases/probi otics.asp

6. Food and Health Agricultural Organization of the United Nations - FAO; World Health Organization. Guidelines for the evaluation of probiotics in food. 2002. Available at: http://www.who.int/foodsafety/fs_management/en/probi otic_guidelines.pdf

7. Roberfroid, M. (1999). Concepts In Functional Foods. Nutrition Today 34(4), 162-65. 
8. Bourdichon, F., Casaregola, S., Farrokh, C., Frisvad, J., Gerds, M., Hammes, W., Harnett, J., Huys, G., Laulund, S., Ouwehand, A., Powell, I. (15). Food fermentations: microorganisms with technological beneficial use. International journal of food microbiology 2012 Mar 154(3), 87-97.

9. Borchers, A., Selmi, C., Meyers, F., Keen, C., Gershwin, M. (2009). Probiotics and immunity. J Gastroenterol 44(1), 2646. https://doi.org/10.1007/s00535-008-2296-0

10. Teitelbaum, J. (). . Pediatric Gastrointestinal and Liver Disease, 4th Edition. Philadelphia: Elseview Inc; 2011:pp.

11. Long, S., Swenson, R. (1977). Development of anaerobic fecal flora in healthy newborn infants. J Pediatr 91, 298-301. https://doi.org/10.1016/S0022-3476

12. Simon, G., Gorbach, S. (1986). The human intestine microflora. Dig Dis Sci 31, 127-62. https://doi.org/10.1007/BF01295996

13. Eckburg, P., Bik, E., Bernstein, C., Purdom, E., Dethlefsen, L., Sargent, M., et, a. (2005). Diversity of the human intestinal microbial flora. Science 308(5728), 1635-8. https://doi.org/10.1126/science.1110591

14. Cruchet, S., Furnes, R., Maruy, A., Hebel, E., Palacios, J., Medina, F., at, a. (2015). The use of probiotics in pediatric gastroenterology: a review of the literature and recommendations by Latin-American experts. Paediatr Drugs 17(3), 199-216. https://doi.org/10.1007/s40272-0150124-6

15. Castagliuolo, I., Riegler, M., Valenick, L., LaMont, J., Pothoulakis, C. (1999). Saccharomyces boulardii protease inhibits the effects of Clostridium difficile toxins $A$ and $B$ in human colonic mucosa. Infect Immun 67(1), 302-7.

16. de, V., Stegelmann, A., Richter, B., Fenselau, S., Laue, C., Schrezenmeir, J. (2001). Probiotics compensation for lactase insufficiency. Am J Clin Nutr 73(Suppl 2), 421S-429S.

17. Hill, C., Guarner, F., Reid, G., Gibson, G., Merenstein, D., Pot, B., et, a. (2014). Expert consensus document. The International Scientific Association for Probiotics and Prebiotics consensus statement on the scope and appropriate use of the term probiotic Nat Rev Gastroenterol Hepatol 11(8),

506-14. https://doi.org/10.1038/nrgastro.2014.66

18. Lebeer, S., Vanderleyden, J., De, K. (2010). Host interactions of probiotic bacterial surface molecules: comparison with commensals and pathogens. Nat Rev Microbiol 8(3), 17184. https://doi.org/10.1038/nrmicro2297

19. Sherman, P., Ossa, J., Johnson-Henry, K. (2009). Unraveling mechanisms of action of probiotics. Nutr Clin Pract 24(1), 10-4. https://doi.org/10.1177/0884533608329231

20. Yan, F., Polk, D. (2006). Probiotics as functional food in the treatment of diarrhea. Curr Opin Clin Nutr Metab Care 9(6), 717-21.

https://doi.org/10.1097/01.mco.0000247477.02650.51

21. Allen, S., Martinez, E., Gregorio, G., Dans, L. (2010). Probiotics for treating acute infectious diarrhoea. Cochrane Database Syst Rev (11)CD003048. https://doi.org/10.1002/14651858.CD003048.pub3

22. Grandy, G., Medina, M., Soria, R., Terán, C., Araya, M. (2010). Probiotics in the treatment of acute rotavirus diarrhoea. A randomized, double-blind, controlled trial using two different probiotic preparations in Bolivian children BMC Infect Dis 10, 253. https://doi.org/10.1186/1471-2334-10-253

23. Dalgic, N., Sancar, M., Bayraktar, B., Pullu, M., Hasim, O. (2011). Probiotic, zinc and lactose-free formula in children with rotavirus diarrhea: are they effective? Pediatr Int. 53(5), 677-82. https://doi.org/10.1111/j.1442200X.2011.03325.x

24. Szymański, H., Pejcz, J., Jawień, M., Chmielarczyk, A., Strus, M., Heczko, P. (15). Treatment of acute infectious diarrhoea in infants and children with a mixture of three Lactobacillus rhamnosus strains--a randomized, double-blind, placebocontrolled trial. Aliment Pharmacol Ther 2006 23(2), 247-53. https://doi.org/10.1111/j.1365-2036.2006.02740.x

25. Chen, C., Kong, M., Lai, M., Chao, H., Chang, K., Chen, S., et, a. (2010). Probiotics have clinical, microbiologic, and immunologic efficacy in acute infectious diarrhea. Pediatr Infect Dis J 29(2), 135-8. https://doi.org/10.1097/INF.0b013e3181b530bf

26. Oberhelman, R., Gilman, R., Sheen, P., Taylor, D., Black, R., Cabrera, L., et, a. (1999). A placebo-controlled trial of Lactobacillus GG to prevent diarrhea in undernourished Peruvian children. J Pediatr 134(1), 15-20. https://doi.org/10.1016/S0022-3476

27. Sur, D., Manna, B., Niyogi, S., Ramamurthy, T., Palit, A., Nomoto, K., et, a. (2011). Role of probiotic in preventing acute diarrhoea in children: a community-based, randomized, double-blind placebo-controlled field trial in an urban slum. Epidemiol Infect 139(6), 919-26. https://doi.org/10.1017/S0950268810001780

28. Heiser, C., Ernst, J., Barrett, J., French, N., Schutz, M., Dube, M. (2004). Probiotics, soluble fiber, and L-Glutamine (GLN) reduce nelfinavir (NFV)- or lopinavir/ritonavir (LPV/r)related diarrhea. J Int Assoc Physicians AIDS Care (Chic) 3(4), 121-9.

29. Anukam, K., Osazuwa, E., Osadolor, H., Bruce, A., Reid, G. (2008). Yogurt containing probiotic Lactobacillus rhamnosus $G R-1$ and $L$. reuteri RC-14 helps resolve moderate diarrhea and increases CD4 count in HIV/AIDS patients J Clin Gastroenterol 42(3), 239-43. https://doi.org/10.1097/MCG.0b013e31802c7465

30. Salminen, M., Tynkkynen, S., Rautelin, H., Poussa, T., Saxelin, M., Ristola, M., et, a. (2004). The efficacy and safety of probiotic Lactobacillus rhamnosus GG on prolonged, noninfectious diarrhea in HIV Patients on antiretroviral therapy: a randomized, placebo-controlled, crossover study. HIV Clin Trials 5(4), 183-91. https://doi.org/10.1310/6F83N39Q-9PPP-LMVV

31. Trois, L., Cardoso, E., Miura, E. (2008). Use of probiotics in HIV-infected children: a randomized double-blind controlled study. J Trop Pediatr 54(1), 19-24. https://doi.org/10.1093/tropej/fmm066

32. Kerac, M., Bunn, J., Seal, A., Thindwa, M., Tomkins, A., Sadler, K., et, a. (2009). Probiotics and prebiotics for severe acute malnutrition (PRONUT study): a double-blind efficacy randomised controlled trial in Malawi. Lancet 374(9684), 136-44. https://doi.org/10.1016/S0140-6736 
33. Shornikova, A., Isolauri, E., Burkanova, L., Lukovnikova, S., Vesikari, T. (1997). A trial in the Karelian Republic of oral rehydration and Lactobacillus GG for treatment of acute diarrhoea. Acta Paediatr 86(5), 460-5. https://doi.org/10.1111/j.1651-2227.1997.tb08913.x

34. Sepp, E., Tamm, E., Torm, S., Lutsar, I., Mikelsaar, M., Salminen, S. (1999). Impact of a Lactobacillus probiotic on the fecal microflora in children with Shigellosis. Microecol Ther 23(1), 74-80.

35. Htwe, K., Yee, K., Tin, M., Vandenplas, Y. (2008). Effect of Saccharomyces boulardii in the treatment of acute watery diarrhea in Myanmar children: a randomized controlled study. Am J Trop Med Hyg 78(2), 214-6.

36. Kurugöl, Z., Koturoğlu, G. (2005). Effects of Saccharomyces boulardii in children with acute diarrhoea. Acta Paediatr 94(1), 44-7. https://doi.org/10.1111/j.16512227.2005.tb01786.x

37. Henker, J., Laass, M., Blokhin, B., Bolbot, Y., Maydannik, V., Elze, M., et, a. (2007). The probiotic Escherichia coli strain Nissle 1917 (EcN) stops acute diarrhoea in infants and toddlers. Eur J Pediatr 166(4), 311-8. https://doi.org/10.1007/s00431-007-0419-x

38. Henker, J., Laass, M., Blokhin, B., Maydannik, V., Bolbot, Y., Elze, M., et, a. (2008). Probiotic Escherichia coli Nissle 1917 versus placebo for treating diarrhea of greater than 4 days duration in infants and toddlers. Pediatr Infect Dis J 27(6), 494-9. https://doi.org/10.1097/INF.0b013e318169034c

39. Vivatvakin, B., Kowitdamrong, E. (). .

40. Sazawal, S., Dhingra, U., Hiremath, G., Sarkar, A., Dhingra, P., Dutta, A., et, a. (2010). Prebiotic and probiotic fortified milk in prevention of morbidities among children: community-based, randomized, double-blind, controlled trial. PLoS One 5(8), e12164. https://doi.org/10.1371/journal.pone.0012164

41. Castaneda, C., Garcia, E., Santa, C., Fernandez, M., Monterrey, P. (1995). Effects of Saccharomyces boulardii in children with chronic diarrhea, especially cases due to giardiasis. Rev Mex Pueric Pediatr 2, 12-16.

42. Mansour-Ghanaei, F., Dehbashi, N., Yazdanparast, K., Shafaghi, A. (2003). Efficacy of saccharomyces boulardii with antibiotics in acute amoebiasis. World J Gastroenterol 9(8), 1832-3.

43. Dinleyici, E., Eren, M., Dogan, N., Reyhanioglu, S., Yargic, Z., Vandenplas, Y. (2011). Clinical efficacy of Saccharomyces boulardii or metronidazole in symptomatic children with Blastocystis hominis infection. Parasitol Res 108(3), 541-5. https://doi.org/10.1007/s00436-010-2095-4

44. McFarland, L. (2006). Meta-analysis of probiotics for the prevention of antibiotic associated diarrhea and the treatment of Clostridium difficile disease. Am J Gastroenterol 101(4), 812-22. https://doi.org/10.1111/j.1572-0241.2006.00465.x

45. Dendukuri, N., Costa, V., McGregor, M., Brophy, J. (2005). Probiotic therapy for the prevention and treatment of Clostridium difficile-associated diarrhea: a systematic review. CMAJ 173(2), 167-70. https://doi.org/10.1503/cmaj.050350
46. Pillai, A., Nelson, R. (2008). Probiotics for treatment of Clostridium difficile-associated colitis in adults. Cochrane Database Syst Rev (1)CD004611. https://doi.org/10.1002/14651858.CD004611.pub2

47. Miller, K., Fraser, T. (2009). Q: What is the role of probiotics in the treatment of acute Clostridium difficile-associated diarrhea? Cleve Clin J Med. 76(7), 391-2. https://doi.org/10.3949/ccjm.76a.08112

48. Hsu, J., Abad, C., Dinh, M., Safdar, N. (2010). Prevention of endemic healthcare-associated Clostridium difficile infection: reviewing the evidence. Am J Gastroenterol. https://doi.org/10.1038/ajg.2010.254

49. Tung, J., Dolovich, L., Lee, C. (2009). Prevention of Clostridium difficile infection with Saccharomyces boulardii: a systematic review. Can J Gastroenterol 23(12), 817-21.

50. Goldenberg, J., Lytvyn, L., Steurich, J., Parkin, P., Mahant, S., Johnston, B. (2015). Probiotics for the prevention of pediatric antibiotic-associated diarrhea. Cochrane Database Syst Rev (12)CD004827. https://doi.org/10.1002/14651858.CD004827.pub4

51. Black, F., Anderson, P., Orskov, J., Gaarlev, K., Laulund, S. (1989). Prophylactic efficacy of Lactobacili on traveller's diarrhea. Travel Med 7, 333-5. https://doi.org/10.1007/978-3-642-73772-5_70

52. Kollaritsch, H., Kremsner, P., Weidermann, G., Scheiner, O. (1989). Prevention of traveler's diarrhea: comparison of different non-antibiotic preparations. Travel Med Int 6, 917.

53. Sazawal, S., Hiremath, G., Dhingra, U., Malik, P., Deb, S., Black, R. (2006). Efficacy of probiotics in prevention of acute diarrhoea: a meta-analysis of masked, randomised, placebo-controlled trials. Lancet Infect Dis 6(6), 374-82. https://doi.org/10.1016/\$1473-3099

54. McFarland, L. (2007). Meta-analysis of probiotics for the prevention of traveler's diarrhea. Travel Med Infect Dis 5(2), 97-105. https://doi.org/10.1016/j.tmaid.2005.10.003

55. Takahashi, O., Noguchi, Y., Omata, F., Tokuda, Y., Fukui, T. (2007). Probiotics in the prevention of traveler's diarrhea: meta-analysis. J Clin Gastroenterol 41(3), 336-7. https://doi.org/10.1097/01.mcg.0000225546.34374.6d

56. Gutierrez-Castrellon, P., Lopez-Velazquez, G., Diaz-Garcia, L., Jimenez-Gutierrez, C., Mancilla-Ramirez, J., EstevezJimenez, J., et, a. (2014). Diarrhea in preschool children and Lactobacillus reuteri: a randomized controlled trial. Pediatrics 133(4), e904-9. https://doi.org/10.1542/peds.2013-0652

57. Agustina, R., Kok, F., van, d., Fahmida, U., Firmansyah, A., Lukito, W., et, a. (2012). Randomized trial of probiotics and calcium on diarrhea and respiratory tract infections in Indonesian children. Pediatrics 129(5), e1155-64. https://doi.org/10.1542/peds.2011-1379

58. Hojsak, I., Močić, P., Kos, T., Dumančić, J., Kolaček, S. (2016). Bifidobacterium animalis subsp. lactis in prevention of common infections in healthy children attending day care centers - Randomized, double blind, placebo-controlled study Clin Nutr 35(3), 587-91. https://doi.org/10.1016/j.clnu.2015.05.004 
59. Bernaola, A., Bada, M., Carreazo, N., Rojas, G. (2013). Probiotics for treating persistent diarrhoea in children. Cochrane Database Syst Rev (8)CD007401. https://doi.org/10.1002/14651858.CD007401.pub3

60. Canani, R., Cirillo, P., Terrin, G., Cesarano, L., Spagnuolo, M., De, V., et, a. (2007). Probiotics for treatment of acute diarrhoea in children: randomised clinical trial of five different preparations. BMJ 335(7615), 340. https://doi.org/10.1136/bmj.39272.581736.55

61. Majamaa, H., Isolauri, E., Saxelin, M., Vesikari, T. (1995). Lactic acid bacteria in the treatment of acute rotavirus gastroenteritis. J Pediatr Gastroenterol Nutr 20(3), 333-8. https://doi.org/10.1097/00005176-199504000-00012

62. Grossi, E., Buresta, R., Abbiati, R., Cerutti, R. (). https://doi.org/10.1097/MCG.0b013e3181e103f4

63. Grandy, G., Medina, M., Soria, R., Terán, C., Araya, M. (2010). Probiotics in the treatment of acute rotavirus diarrhoea. A randomized, double-blind, controlled trial using two different probiotic preparations in Bolivian children BMC Infect Dis 10, 253. https://doi.org/10.1186/1471-2334-10-253

64. Jasinski, C., Tanji, M., Schelotto, F., et, a. (2002). Efficacy of lactobacillus $G G$ in oral rehydration solution. Pediatrika 22(7), 231-43.

65. Guandalini, S. https://doi.org/10.1097/MCG.0b013e3181674087

66. Basu, S., Chatterjee, M., Ganguly, S., Chandra, P. (2007). Efficacy of Lactobacillus rhamnosus GG in acute watery diarrhoea of Indian children: a randomised controlled trial. J Paediatr Child Health 43(12), 837-42. https://doi.org/10.1111/j.1440-1754.2007.01201.x

67. Khanna, V., Alam, S., Malik, A., Malik, A. (2005). Efficacy of tyndalized Lactobacillus acidophilus in acute diarrhea. Indian J Pediatr 72(11), 935-8. https://doi.org/10.1007/BF02731667

68. Costa-Ribeiro, H., Ribeiro, T., Mattos, A., Valois, S., Neri, D., Almeida, P., et, a. (2003). Limitations of probiotic therapy in acute, severe dehydrating diarrhea. J Pediatr Gastroenterol Nutr 36(1), 112-5. https://doi.org/10.1097/00005176200301000-00021

69. Mao, M., Yu, T., Xiong, Y., Wang, Z., Liu, H., Gotteland, M., et, a. (2008). Effect of a lactose-free milk formula supplemented with bifidobacteria and streptococci on the recovery from acute diarrhoea. Asia Pac J Clin Nutr 17(1), 30-4.

70. Ritchie, B., Brewster, D., Tran, C., Davidson, G., McNeil, Y., Butler, R. (2010). Efficacy of Lactobacillus GG in aboriginal children with acute diarrhoeal disease: a randomised clinical trial. J Pediatr Gastroenterol Nutr 50(6), 619-24. https://doi.org/10.1097/MPG.0b013e3181bbf53d

71. Sarker, S., Sultana, S., Fuchs, G., Alam, N., Azim, T., Brüssow, H., et, a. (2005). Lactobacillus paracasei strain ST11 has no effect on rotavirus but ameliorates the outcome of nonrotavirus diarrhea in children from Bangladesh. Pediatrics 116(2), e221-8. https://doi.org/10.1542/peds.2004-2334

72. Szajewska, H., Setty, M., Mrukowicz, J., Guandalini, S. (2006). Probiotics in gastrointestinal diseases in children: hard and not-so-hard evidence of efficacy. I Pediatr Gastroenterol Nutr 42(5), 454-75. https://doi.org/10.1097/01.mpg.0000221913.88511.72

73. Vandenplas, Y., Salvatore, S., Vieira, M., Devreker, T., Hauser, B. (2007). Probiotics in infectious diarrhoea in children: are they indicated? Eur J Pediatr. 166(12), 1211-8. https://doi.org/10.1007/s00431-007-0497-9

74. Floch, M., Walker, W., Sanders, M., Nieuwdorp, M., Kim, A., Brenner, D., et, a. (). https://doi.org/10.1097/MCG.0000000000000420

75. Gupta, V., Garg, R. (2009). Probiotics. Indian J Med Microbiol 27(3), 202-9. https://doi.org/10.4103/02550857.53201

76. Guarino, A., Lo, V., Canani, R. (2009). Probiotics as prevention and treatment for diarrhea. Curr Opin Gastroenterol 25(1), 18-23. https://doi.org/10.1097/MOG.0b013e32831b4455

77. Thomas, D., Greer, F., , ., and, N. (2010). Probiotics and prebiotics in pediatrics. Pediatrics 126(6), 1217-31. https://doi.org/10.1542/peds.2010-2548

78. Guarino, A., Albano, F., Ashkenazi, S., Gendrel, D., Hoekstra, J., Shamir, R., et, a. (). https://doi.org/10.1097/MPG.0b013e31816e219e

79. Platincx, M., Legein, J., Vandenplas, Y. (1995). Fungemia with Saccharomyces boulardii in a 1-year-old girl with protracted diarrhea. J Pediatr Gastroenterol Nutr 21, 113-5.

80. Patel, R., Cockeril, F., Porayko, M., et, a. (1994). Lactobacillemia in liver transplant patients. Clin Infect Dis 18, 207-12. https://doi.org/10.1093/clinids/18.2.207

81. Kunz, A., Noel, J., Fairchol, M. (2004). Two cases of Lactobacillus bacteremia during probiotic treatment of short gut syndrome. J Pediatr Gastroenterol Nutr 38, 557-8.

82. Dai, M., Lu, J., Wang, Y., Liu, Z., Yuan, Z. (2012). In vitro development and transfer of resistance to chlortetracycline in Bacillus subtilis. J Microbiol 50(5), 807-12. https://doi.org/10.1007/s12275-012-1454-5 